Малишенко Л. О., Михайловська О. П., Одеський торговельно-економічний інститут Київського національного торговельно-економічного університету

\title{
КОНСТРУКТИ ЕЛЕКТРОННОЇ ДЕМОКРАТІЇ ЯК ВИРІШАЛЬНІ ЧИННИКИ ФОРМУВАННЯ «ПОРЯДКУ ДЕННОГО» СУСПІЛЬНО-ПОЛІТИЧНОГО ЖИТТЯ
}

Показано, що сучасні інформачійно-комунікативні технологї̈ постають вирімальним чинником формування «порядку денного» суспільно-політичного життя і є безпосереднім засобом організаиї прямих сочіальних дій, зокрема - нових моделей управління. Електронну демократію часто розглядають як варіант «відкритого коду», коли законопроєкти публікуються в інформаиійних мережах, а користувачі можуть внести в їх зміст будь-які зміни і у такий спосіб взяти безпосередню участь у прийнятті політичних рішень.

Однак поряд з оптимістичними прогнозами використання інформаиійних технологій наростає й тривога, пов'язана з посиленням можливості для маніпулювання суспільною думкою, зміџнення з їхньою допомогою владної ієрархї̈, реалізачією корисливих інтересів власників ЗМІ. 3 'явилися також сумніви із приводу підвищення політичної активності громадян завдяки інформаційним технологіям у зв'язку з зростанням абсентеїзму й збільшенням чисельності протестного електорату.

Індивідуалізація політики й суспільства може зробити практично неможливими й навіть небезпечними спроби досягти інтеграції й консенсусу. Політичний контроль і електронна доступність виявляються взаємовиключними в існуючій політичній системі. Використання громадянами Інтернету як інструмента одержання інформації, комунікаиії й організації може привести до відходу від основного державного політичного курсу.

Таким чином, сучасний політичний простір повною мірою усвідомив ті колосальні переваги, які несе із собою розвиток $і$ поширення інформачійно-комунікаційних технологій, однак $i$, безумовно, $i$ негативні прояви, і тому ці відносно нові тенденції не можна вважати як панацею від усіх проблем створення світопорядку наприкінці XX-у перші десятиліття XXI століть.

Ключові слова: інформачійно-комунікативні технології, інформачійні мережі, електронна демократія, електронне урядування, «відкритий код», індивідуалізачія політики й суспільства, маніпулювання суспільною думкою.

Процеси, пов'язані з накопиченням, обробкою, передачею та збереженням інформації, завжди мали визначальний характер у будь-яких явищах соціальної самоорганізації протягом усієї історії людства Початком ери інформації й знань можна вважати приблизно 50-ті роки мінулого століття, коли ці показники стали займати не менш важливе місце, ніж капітал і праця в індустріальному суспільстві.

Одна 3 найважливіших функцій сучасних інформаційно-комунікативних технологій полягає у тому, що вони стають вирішальним чинником формування «порядку денного» суспільнополітичного життя, тобто виступають універсальним засобом надання статусу та ієрархічності суспільним проблемам, особам, організаціям та громадським рухам і є безпосереднім засобом організації прямих соціальних дій, зокрема - нових моделей управління. Тому не викликає жодних сумнівів як теоретична, так і практична актуальність дослідження цих сучасних тенденцій i процесів, їх загальних та специфічних рис в різних регіонах світу.

Метою статті $\epsilon$ визначення теоретичних та політико-правових засад е-демократії, зокрема е-уряду уряду, як моделі управління, яка заснована на сучасних інформаційних і комунікаційних технологіях.

Досягнення визначеної мети передбачає вирішення таких завдань:

- проаналізувати світовий досвід формування та розвитку е-урядування та його впливу на політичні процеси;

- обгрунтувати необхідність упровадження практик е-демократії і електронного урядування в сучасній Україні та визначити позитивні і негативні наслідки даного процесу. 
Методи дослідження. Відповідно до поставленої мети та завдань авторами статті використано загальнонаукові та спеціальні політологічні методи дослідження, що забезпечують єдність гносеологічного, соціально-філософського та політологічного аналізу досліджуваної проблематики. Вони базуються на принципах історизму, об'єктивності, системності, послідовності, конкретизації та соціального детермінізму.

Нові технології змінили пріоритети в політиці у результаті виниклої залежності між інформаційною системою й політичним ринком у реальному часі. Розвиток інформаційного суспільства, пов'язаного з розвитком інформаційних i комунікативнизх технологій, поставив на порядок денний модель «демократії участі».

Як відомо, вперше особливе значення можливостям Інтернету в цілому, е-демократії - зокрема, надалі у США в 1991 р. під час президентства Б. Клінтона. 3 кінці 90-х років цей термін став регулярно використовуватись в провідних ЗМІ США, а потім й інших розвинених держав. I найбільш чітко це знайшло відображення в електоральному процесі.

Це сталося не на «порожньому місці».Так, 3 кінця 1960-х років, коли при підрахунку голосів стали використовувати комп'ютери, з'являється так звана «стратегія голосування». Її суть полягає в тестуванні різних політичних стратегій на фокус-групах потенційних виборців, коли за мірою появи результатів змінюються самі стратегії. В остаточному підсумку, іміджмейкери й особи, що проводили опитування, ставали, по суті, головними політичними діячами: за допомогою інформаційних технологій i засобів ЗМІ вони могли «створювати» президентів, сенаторів, конгресменів, міністрів.

Один 3 найбільш відомих дослідників у цьому напряму М. Кастельс пропонує три варіанти розвитку подій. Перший шлях припускає створити нове місцеве самоврядування. У багатьох державах демократія на місцях була покликана допомогти процвітанню суспільства, принаймні, у рамках національної політичної демократії. Цього вдавалося досягти у випадках, коли регіональні й місцеві уряди, кооперуючи свої дії, досягали певної децентралізації й підвищення рівня громадської участі. Поява електронних носіїв у ще більшому ступені стимулює політичну участь на місцевому рівні, але й підсилює дроблення держав-націй.

Другий шлях пропонує як альтернативу політичній участі й встановлення горизонтальних комунікацій громадян 3 державними органами використовувати електронні комунікації. Он-лайновий доступ до інформації за допомогою персональних комп’ютерів дозволяє громадянам влаштовувати політичні дебати й обговорення в електронних форумах, минаючи, тим самим, контроль і думку, що нав'язується ЗМІ. В цих умовах громадяни формують свої власні політичні й ідеологічні співтовариства, обходячи, таким чином, встановлені державою політичні структури й створюючи гнучкі форми політичного простору.

Однак, такий варіант розвитку викликав серйозну критику перспектив електронної демократії. 3 одного боку, поява цієї форми демократії як інструмента політичних дебатів, представлення політичних ідей і рішень сприймається як інституціоналізована форма «афінської демократії», коли відносно невелика, утворена й впливова елітна група людей володіє важливою інформацією. У результаті більша маса неосвічених громадян виявляється за межами цієї нової форми демократії, як це було з рабами, жінками й іноземцями в Стародавній Греції. 3 іншого боку, засоби масової інформації часто наголошують на «політичному шоу» 3 усіма його особливостями, підмінюючи реальну політику.

Індивідуалізація політики й суспільства може зробити практично неможливими й навіть небезпечними спроби досягти інтеграції й консенсусу. Слід також зазначити, що електронна політика може й повинна обмежувати відкритість і доступність системи електронної демократії. Як правило, кандидати, що розміщають ту або іншу інформацію в електронних мережах, не несуть за неї відповідальності при електронному спілкуванні 3 електоратом. Політичний контроль i електронна доступність виявляються взаємовиключними в існуючій політичній системі. Якщо політичні партії й організації тримають під контролем політичні процеси, а політична участь громадян у мережі є невід’ємною частиною інформаційної політики, слідством цього може бути формалізація виборів і прийняття політичних рішень. При цьому використання громадянами Інтернету як інструмента одержання інформації, комунікації й організації може привести до відходу від основного державного політичного курсу.

Для відновлення демократії в мережному суспільстві третій шлях припускає розвиток «політики символів», тобто політики віртуального мережного суспільства, заснованої на актуальному досвіді в реальності і зосередження політичних інтересів на неполітичних подіях. Такі організації, як «Міжнародна амністія», «Гринпіс» i безліч інших місцевих i міжнародних груп активістів i 
недержавних організацій $\epsilon$ основними, найбільш потужними й мобільними учасниками інформаційної політики. Вони звертаються безпосередньо до громадян. Відстоюючи інтереси населення, такі організації вважають своєю метою участь у керуванні політичними процесами в державі. Причому зовсім необов'язково, що подібні організації мають прагнути до влади шляхом впровадження своїх кандидатів у державні органи. Не перетворюючись у політичні партії, вони, проте, стимулюють нові політичні процеси й процедури, які впораються із кризою ліберальної класичної демократії на шляху створення нової - електронної [1, с. 145].

Поряд 3 оптимістичними прогнозами використання інформаційних технологій наростає й тривога, пов'язана з посиленням можливості для маніпулювання суспільною думкою, зміцнення з їхньою допомогою владної ієрархії, реалізацією корисливих інтересів власників ЗМІ. 3'явилися також сумніви із приводу підвищення політичної активності громадян завдяки інформаційним технологіям у зв'язку з зростанням абсентеїзму й збільшенням чисельності протестного електорату.

Негативні прогнози щодо ролі інформаційних технологій у розвитку інформаційного суспільства й демократії пов'язані з роботами М. Догана та ін. Так, можна відзначити наступні небезпечні тенденції:

- величезне зростання інформації, що накопичується й розповсюджується за допомогою Інтернету, приводить до засмічення всесвітньої мережі «інформаційним сміттям» і інформаційним перевантаженням. В цих умовах своєрідною захисною реакцією більшості громадян стає обмеження використання он-лайнових політичних джерел;

- проблема демократії сьогодні не в дефіциті механізмів політичної участі громадян, а в розчаруванні мас у самій політиці, у посиленні їхньої незадоволеності діяльністю політичних інститутів, що викликає втрату віри в здатність існуючої політичної системи адекватно реагувати на суспільні потреби;

- «цифрова нерівність» породила пророкування щодо появи нової он-лайнової еліти, що впливає на процес прийняття рішень, у той час як більшість населення відсторонена від нього;

- хакерство, що являє собою застосування Інтернет-технологій з метою завдання збитків корпоративним або індивідуальним користувачам всесвітньої мережі, стало невід'ємною частиною інформаційних технологій. Однією з перших таких організацій став так званий «Театр електронних безлад», що був створений у середині 1990-х років американським художником і артистом Р. Домінгесом. Група осіб, що підтримують його організацію, на початку виражати свій соціальний протест за допомогою технологій Інтернету шляхом блокування або перевантаження сайтів деяких політичних організацій, чиєю діяльністю вони не були задоволені.

Інтернет відкриває можливості не тільки для активізації громадян у політичних процесах, але й для освоєння електронного простору екстремістськими організаціями різної спрямованості (неонацисти, скінхеди, расисти, релігійні фанатики) з метою поширення своїх поглядів і залучення у свої організації нових послідовників.

Поява в США i Японії на початку 70 -х років XX століття кабельного телебачення з розширеними можливостями (з різноманітним змістом, каналом зворотного зв'язка із глядачами, поданням передплатникам локально значимої інформації), надало впевненості прихильникам ідеї широкого використання технічних засобів в організації демократичних процедур, що, нарешті, дало можливість технічної організації дистанційних соціальних взаємодій.

У зв'язку із цим, ще в 1983 році А. де Сола Пул затверджував, що нові технології зв'язку - це технології волі, які забезпечать можливість реалізації на практиці принципів волі слова тією мірою, якою їх ще ніколи не знало людство. Інший дослідник - К. Артертон в 1987 році писав про теледемократію, що прокладені мережі зв'язку дозволять перевести демократію на новий рівень i, одночасне, використання сучасних технологій зможе гарантувати представницькі процеси й плюралізм у політиці. Ще один американський автор Л. Віннер, наприкінці 70-х років стверджував, що абсолютно всі використовувані в суспільних взаємодіях електронні технології дуже важні для організації соціального життя [Див.: 2].

О. Тоффлер і Д. Нейсбіт вважали, що саме теледемократія вже в доступному майбутньому допоможе вирішенню більшості з найбільш актуальних проблем соціального розвитку. Як відзначав О. Тоффлер, мова при цьому йде про більш активну участь громадян у прийнятті політичних рішень. Нові медіа й засоби телекомунікацій повинні наблизити державу безпосередньо до громадян, надати технічні засоби для здійснення прямої демократії [3, с. 238].

Однак вже в середині 80-х років XX століття стало ясно, що експерименти з використанням кабельного телебачення не привели до нових форм демократії та активізації політичної активності 
громадян. Тому Р. Даль, не вбачаючи реальних перспектив поліпшення ситуації, рекомендував колегам чекати нового покоління «теледемократичних» технічних устроїв [4, с. 342].

На початку 90-х років ХХ століття в США дискусія про теледемократію розгорнулася 3 новою силою, стимулом якої став кандидат у президенти США Р. Перо. Впровадження у життя американського суспільства технологій теледемократії стало частиною його передвиборної платформи. Б. Клінтон також широко використовував, для залучення на свою сторону електорату, прямі телевізійні трансляції зборів жителів міст, що для того часу було досить революційним кроком [Цит. за: 5, с. 13].

Після закінчення президентських виборів у США з'явилася ще одна причина ренесансу теледемократії, яка була пов'язана із принципово новими технологічними рішеннями, зокрема, з появою технологій кабельного телебачення, що дозволяло транслювати до п'ятисот телевізійних каналів. Л. К. Гроссман вважав, що у багатьох своїх проявах телебачення закладає фундамент майбутньої електронної республіки. Фундамент цей базується на теоретичному каркасі можливих напрямків реформування сфери громадського життя, розробленому наприкінці 80-х років ХХ століття Ю. Хабермасом. 3 погляду Ю. Хабермаса, кіберпростір - це нова «суспільна сфера», яка повинна стати простіром вільних обговорень про актуальні суспільні проблеми, сферою, в якій кожний громадянин може не тільки висловитися, але й бути почутим [6, с. 14].

Американські політологи С. Сун і Г. Барнетт, вивчивши співвідношення між структурою телефонних мереж і процесами демократизації в суспільстві, прийшли до висновку про найважливу роль розвитку телекомунікаційної інфраструктури в питаннях функціонування демократії.

Слідом за телефоном ще більшу революцію в питаннях організації людських взаємодій зробили персональні комп'ютери. Ще на початку їхньої появи Дж. Гілдер вів мову про те, що об’єднані мережі комунікацій i комп’ютери не тільки нададуть технологічну платформу для росту комунікативних взаємодій, але й підсилюють демократію.

Ще один американський дослідник М. Капор в 1993 році писав про величезний потенціал комп'ютерної мережі Інтернет у питаннях здійснення революції в методах управління в суспільстві. Засновник i ідеолог одного 3 перших віртуальних мережних співтовариств Г. Рейнгольд також висловлював переконання в тому, що віртуальні співтовариства могли б допомогти громадянам пожвавити демократію. Інший американський автор Т. Росзак, говорячи про загальну атмосферу кіберпростіру, звертав увагу на «спонтанно демократичний $\mathrm{i}$ лібертаріанський дух», що відрізняв віртуальні мережні співтовариства. Соціолог же Г. Бухстайн затверджував, що електронні засоби комунікації допоможуть вирішити багато проблем, які дотепер робили модель прямої демократії непрактичною. У свою чергу К. Мітч писав про те, що технології повинні в першу чергу розглядатися як засоби, які актори або суспільство використовують для досягнення заздалегідь визначених соціальних цілей. Відповідно, ідеологія технологічного детермінізму не може бути теоретичною підставою для зміни характеру соціальних взаємодій [Цит. за: 7, с. 78-79].

На початку 90-х років ХX століття в західних країнах теоретичні конструкти електронної демократії стали втілюватися в експериментальних проектах. Відбувалося це не на основі кабельних мереж і телебачення, а вже на новій технологічній базі, яку склали суспільні телекомунікаційні мережі й комп'ютери.

Дослідники розглядають варіант використання інформаційних технологій як так звані «електронні урни», які можуть працювати без підключення до електромережі та комунікаційної інфраструктури. Обгрунтовують такий варіант використанням можливостей мережі у малонаселенних пунктах, що ерріторіально віддалені та нетелефонізовані. Прикладом є досвід Бразилії, де в 2002 році були вперше в світі проведені електронні загальнонаціональні вибори глави держави. Шоправда, «електронні урни» не виключають можливість фальсифікації результатів голосування, унаслідок втручання як у процес підготовки обладнання, так і під час застосування програмного забеспечення [8, с. 133-134].

Тем не менш, у першу чергу мова йде про трансформацію самих принципів взаємодії влади $і$ громадянського суспільства, коли громадяни, як об’єкт владного керівництва, перетворюється у компетентного користувача послугами, що надаються більш-менш розвиненим інформаційним суспільством, і одночасно стають учасником процесу прийняття політичних рішень як на місцевому, регіональному, так і загальнодержавному рівнях.

Електронну демократію часто розглядають як варіант «відкритого коду», коли законопроєкти публікуються в інформаційних мережах, а зареєстровані користувачі можуть внести в їх зміст будьякі зміни і у такий спосіб взяти безпосередню участь у прийнятті політичних рішень. 
Практичне застосування єлекронной демократії найчастіше пов'язують 3 е-урядуванням, багатий досвід функціонування якого мають Канада, США, Франція, ФРН. На жаль, країни пострадянського простору не мають такого багаторічного досвіду, і тому намагаються креативно використовувати зарубіжні наробки, вносячи властиві їм специфічні риси.

Отже, в умовах глобалізації соціальних і економічних процесів інформаційні технології виступають одним 3 найбільш важливих факторів, що впливають на формування суспільства XXI століття. Завдяки високим технологіям створюються віртуальні держави, на кшталт Вільної бірманської коаліції (Free Burma Coalition), яка перебуває лише в кіберпросторі й пропонує співробітництво й солідарність.

Таким чином, сучасний політичний простір повною мірою усвідомив ті колосальні переваги, які несе із собою розвиток і поширення інформаційно-комунікаційних технологій, однак i, безумовно, i негативні прояви, і тому ці відносно нові тенденції не можна вважати як панацею від усіх проблем створення світопорядку наприкінці XX - у перші десятиліття XXI століть.

\section{Бібліографічний список:}

1. Кастельс М. Информационная эпоха: экономика, общество и культура / М. Кастельс; Пер. с англ., под науч. ред. О. И. Шкаратана. - М.: ГУВШ, 2000.

2. Агамирзян И. Р. Мировой опыт реализации концепции электронного правительства // Технологии информационного общества - Интернет и современное общество / И. Р. Агамирзян. - СПб.: Изд-во С.-Петерб. ун-та, 2002. - С. 255-258.

3. Тоффлер Э. Метаморфозы власти: Знание, богатство и сила на пороге XXI века / Э. Тоффлер. М.: АCT, 2001. $-669 \mathrm{c}$.

4. Даль Р. Демократия и ее критики / Р. Даль; Пер. с англ. - М.: РОССПЭН, 2003. - 576 с.

5. Робачевский А. Инфраструктура Интернет в США / А. Робачевский // INTERNET Journal. - 2006. № 3. - C. 12-14.

6. Хабермас Ю. Демократия. Разум. Нравственность: Лекции и интервью / Ю. Хабермас. Москва, апрель 1989 г. - М., 1989. - C. 14-18.

7. Дослідження політики в системі Інтернет / Чернівецький національний ун-т ім. Юрія Федьковича / [Упоряд. В. І. Бурдяк, І. С. Осадца]. - Чернівці: Рута, 2005. - 39 с.

8. Митко А. Демократія електронна / А. Митко // Навчальний енциклопедичний словник-довідник / за наук. ред. Н. М. Хоми. - Львів: «Новий Світ - 2000», 2014. - 779 с. - С. 133-134.

\section{Malishenko L. O., Mikhailovska O. P. Structures of e-democracy as the main factors of socio-political life agenda forming.}

It is shown that modern information and communication technologies are a decisive factor in the formation of the «agenda» of socio-political life and are a direct means of organizing direct social actions, in particular - new models of management. Electronic democracy is often seen as an "open source» option when bills are published in information networks, and users can make any changes to their content and thus take direct part in making policy decisions.

However, along with the optimistic forecasts of the use of information technologies, anxiety that is associated with increased opportunities for manipulating public opinion, strengthening with their help of the power hierarchy, and the realization of selfish interests of media owners increases. There were also doubts about the increase in political activity of citizens due to information technologies in connection with the growth of absenteeism and an increase in the number of protest electorates.

Individualization of politics and society can make practically impossible and even dangerous attempts to achieve integration and consensus. Political control and electronic accessibility are mutually exclusive in the existing political system. The use of Internet by citizens as a tool for obtaining information, communication and organization can lead to a departure from the main political policy of the state. Thus, modern political space has fully realized the enormous advantages that accompany the development and spread of information and communication technologies, but, of course, also negative manifestations, and therefore these relatively new trends can not be considered as a panacea for all the problems of creating a world order at the end of the XX - in the first decades of the XXI century.

Key words: information and communication technologies, information networks, electronic democracy, e-government, "open source», individualization of politics and society, manipulation of public opinion. 